\title{
Multimineral nutritional supplements in a nano-CaO matrix
}

\section{Journal Article}

Author(s):

Knijnenburg, Jesper T. N.; Hilty, Florentine M.; Krumeich, Frank; Zimmermann, Michael B.; Pratsinis, Sotiris E.

Publication date:

2013-04

Permanent link:

https://doi.org/10.3929/ethz-b-000065701

Rights / license:

In Copyright - Non-Commercial Use Permitted

Originally published in:

Journal of Materials Research 28(8), https://doi.org/10.1557/jmr.2013.63 


\title{
Multimineral nutritional supplements in a nano-CaO matrix
}

\author{
Jesper T.N. Knijnenburg \\ ETH Zurich, Particle Technology Laboratory, Institute of Process Engineering, Department of Mechanical \\ and Process Engineering, CH-8092 Zurich, Switzerland
}

Florentine M. Hilty

ETH Zurich, Particle Technology Laboratory, Institute of Process Engineering, Department of Mechanical and Process Engineering, CH-8092 Zurich, Switzerland; and ETH Zurich, Human Nutrition Laboratory, Institute of Food, Nutrition and Health, Department of Health Sciences and Technology, CH-8092 Zurich, Switzerland

Frank Krumeich

ETH Zurich, Laboratory of Inorganic Chemistry, Department of Chemistry and Applied Biosciences, CH-8093 Zurich, Switzerland

Michael B. Zimmermann

ETH Zurich, Human Nutrition Laboratory, Institute of Food, Nutrition and Health, Department of Health Sciences and Technology, CH-8092 Zurich, Switzerland

Sotiris E. Pratsinis ${ }^{\text {a }}$

ETH Zurich, Particle Technology Laboratory, Institute of Process Engineering, Department of Mechanical and Process Engineering, CH-8092 Zurich, Switzerland

(Received 14 November 2012; accepted 8 March 2013)

\begin{abstract}
The fast dissolution of certain calcium-containing compounds makes them attractive carriers for trace minerals in nutritional applications, e.g., iron and zinc to alleviate mineral deficiencies in affected people. Here, $\mathrm{CaO}$-based nanostructured mixed oxides containing nutritionally relevant amounts of $\mathrm{Fe}, \mathrm{Zn}, \mathrm{Cu}$, and $\mathrm{Mn}$ were produced by one-step flame spray pyrolysis. The compounds were characterized by nitrogen adsorption, x-ray diffraction, (scanning) transmission electron microscopy, and thermogravimetric analysis. Dissolution in dilute acid (i.d.a.) was measured as an indicator of their in vivo bioavailability. High contents of calcium resulted in matrix encapsulation of iron and zinc preventing formation of poorly soluble oxides. For $3.6 \leq \mathrm{Ca}: \mathrm{Fe} \leq 10.8, \mathrm{Ca}_{2} \mathrm{Fe}_{2} \mathrm{O}_{5}$ coexisted with $\mathrm{CaO}$. For $\mathrm{Ca} / \mathrm{Zn}$ compounds, no mixed oxides were obtained, indicating that the $\mathrm{Ca} / \mathrm{Zn}$ composition can be tuned without affecting their solubility i.d.a. Aging under ambient conditions up to 225 days transformed $\mathrm{CaO}$ to $\mathrm{CaCO}_{3}$ without affecting iron solubility i.d.a. Furthermore, $\mathrm{Cu}$ and $\mathrm{Mn}$ could be readily incorporated in the nanostructured $\mathrm{CaO}$ matrix. All such compounds dissolved rapidly and completely i.d.a., suggesting good in vivo bioavailability.
\end{abstract}

\section{INTRODUCTION}

Iron deficiency (ID) affects over 2 billion people worldwide $^{1}$ and is among 10 leading global risk factors for disease, disability, and death. ${ }^{2}$ The WHO estimates that $39-52 \%$ of women and children in developing countries are anemic, ${ }^{2}$ with half of the anemia from ID. ${ }^{3}$ The latter is also common in industrialized countries: in the UK, $21 \%$ and 18\% of 11-18 years-old and 16-64 years-old females, respectively, are iron deficient, ${ }^{4}$ and in the US, iron deficiency anemia (IDA) affects up to $27 \%$ of pregnant women. ${ }^{5}$ The high prevalence of ID has a substantial negative impact on health and economic prosperity. ${ }^{3}$ IDA increases risk for maternal death, low birth weight, and infant mortality, ${ }^{3}$ while in adults, physical work capacity is reduced. ${ }^{6}$

\footnotetext{
a) Address all correspondence to this author.

e-mail: pratsinis@ptl.mavt.ethz.ch

DOI: $10.1557 /$ jmr.2013.63
}

Similar to ID, zinc deficiency affects approximately $30 \%$ of the world population, mainly in Southeast Asia (33\% of the population) but also in Western Europe $(11 \%)$ and US/Canada $(10 \%){ }^{7}$ Since zinc is involved in many metabolic pathways, its deficiency results in a wide range of adverse outcomes. During growth, low zinc status can negatively influence growth, sexual development, and skeletal maturation, while the integrity of the immune system may be compromised. ${ }^{7}$

Three main strategies are utilized to reduce nutritional deficiencies: food diversification, food fortification, and supplementation. ${ }^{1}$ Supplementation, the provision of additional micronutrients taken in a form other than as foods can be effective, especially if targeted to specific population groups. ${ }^{8}$ However, low compliance and in developing countries also ineffective supply are major limiting factors of success. ${ }^{1,3}$

In Europe ${ }^{9,10}$ approximately $15-20 \%$ and in the US ${ }^{11}$ up to $50 \%$ of the population consume supplements. 
Most widely consumed are multivitamin/multimineral preparations ${ }^{9,11}$ with $\mathrm{Ca}$ and $\mathrm{Mg}$ either as main components ${ }^{12}$ or as single mineral supplements. ${ }^{9,11}$ Inorganic Ca compounds like $\mathrm{CaO}, \mathrm{Ca}(\mathrm{OH})_{2}$, and $\mathrm{CaCO}_{3}$ are approved for supplementation in the US ${ }^{13}$ and the European Union. ${ }^{13,14}$ These compounds are considered to be bioavailable and can contribute to meeting requirements in humans. $^{15}$

Conventionally prepared multimineral supplements require a homogeneous and stable mixture of different ingredients before pressing tablets. This is often a challenge because size, shape, density, and surface characteristics of each powder influence the mixing process. Especially size differences are a serious cause of segregation in powder mixing. ${ }^{16}$ Mixing nanostructured powders is especially challenging because their strong interparticle forces make it difficult to break up agglomerates. ${ }^{17}$

Nanostructured iron and zinc compounds have promising applications in nutrition for their high bioavailability and low reactivity. ${ }^{18,19}$ Iron from mixed nanostructured $\mathrm{Fe} / \mathrm{Zn} / \mathrm{Mg}$ oxides is as bioavailable in rats as iron from $\mathrm{FeSO}_{4}$, the "gold standard." ${ }^{20}$ The specific surface area (SSA) and thus the particle size is a major determinant of dissolution and bioavailability kinetics. ${ }^{21-23}$ However, even at the nanoscale, chemical composition is still important as shown for calcium-containing iron oxides with low SSA but good dissolution in dilute acid (i.d.a., 0.1 M $\mathrm{HCl}, \mathrm{pH} 1),{ }^{24}$ a good in vitro predictor for in vivo iron bioavailability. ${ }^{21}$ The addition of $\mathrm{Ca}$ or $\mathrm{Mg}$ results in solid solutions and mixed oxides with iron oxide (e.g., $\mathrm{Ca}_{2} \mathrm{Fe}_{2} \mathrm{O}_{5}$ and $\mathrm{MgFe}_{2} \mathrm{O}_{4}$ ), decreasing lattice energy and therewith improving iron dissolution. ${ }^{24}$

Here, we use fast-dissolving nano- $\mathrm{CaO}$ as a carrier matrix for $\mathrm{Fe}$ and/or $\mathrm{Zn}$. These $\mathrm{CaO}$-based nanostructured compounds were prepared by flame spray pyrolysis (FSP). ${ }^{25}$ This simple, scalable one-step process can produce homogeneous powders that are mixed on the nano- or atomic-scale, ${ }^{26}$ avoiding mixing and segregation issues. The relative metal composition in these powders was based on their recommended dietary allowance/adequate intake (RDA/AI) levels for males aged 19-50 years: $1000 \mathrm{mg}$ for $\mathrm{Ca}, 8 \mathrm{mg}$ for $\mathrm{Fe}$, and $11 \mathrm{mg}$ for $\mathrm{Zn} .{ }^{27}$ Because of the higher daily requirement of calcium compared with iron and zinc, dopant levels of the latter are embedded in a calcium-based matrix by forming solid solutions or mixed oxides with $\mathrm{CaO}$. It is shown here that $\mathrm{Fe}$ or $\mathrm{Zn}$ solubility i.d.a. remains high irrespective of SSA and phase composition. Also elements such as $\mathrm{Cu}$ or $\mathrm{Mn}$ can be incorporated with potentially high bioavailability. The use of inexpensive nitrate precursors and ethanol-based solvents lowers the manufacturing cost of these nanostructured powders, making them promising for multimineral supplement preparations.

\section{MATERIALS AND METHODS}

Nanostructured compounds were produced by FSP. ${ }^{25}$ The precursors were mixtures of $\mathrm{Ca}$ (II)-nitrate tetrahydrate (puriss. p.a., $\geq 99 \%$, Fluka, Sigma-Aldrich Chemie GmbH, Buchs, Switzerland), $\mathrm{Fe}(\mathrm{III})$-nitrate nonahydrate (puriss. $\geq 97 \%$, Riedel-de-Haën, Sigma-Aldrich Chemie $\mathrm{GmbH}$, Buchs, Switzerland), Zn(II)-nitrate hexahydrate (purum p.a., $\geq 99 \%$, Fluka), Mn(II)-nitrate tetrahydrate (purum. $\geq 96.0 \%$, Riedel-de-Haën), and/or Cu(II)-nitrate hemipentahydrate $(\geq 98.0 \%$, Sigma-Aldrich, Buchs, Switzerland) dissolved in a 1:1 mixture by volume of ethanol (abs. denat. 2\% 2-butanone, Alcosuisse, Bern, Switzerland) and 2-ethylhexanoic acid (2-EHA, purum $>99 \%$, Riedel-de-Haën). ${ }^{20,24}$ The total metal concentration in the precursor was $0.5 \mathrm{M}$.

The precursor solution was fed into the water-cooled FSP reactor nozzle using a syringe pump (Inotech R232, Inotech Labor AG, Basel, Switzerland) and dispersed by $\mathrm{O}_{2}$ (PanGas, Zurich, Switzerland, purity 99.95\%) maintaining a pressure drop of 1.8 bar over the nozzle. The spray was ignited by a premixed methane/oxygen $(1 / 2 \mathrm{~L} / \mathrm{min}) \mathrm{ring}$ shaped flame. ${ }^{20}$ Particles were collected on a glass fiber filter (GF/D Whatman, $257 \mathrm{~mm}$ diameter, Whatman Ltd., Maidstone, UK) placed in a water-cooled holder $50-70 \mathrm{~cm}$ above the burner. Flame parameters are denoted by $x / y$, where $x$ is the precursor feed rate $(\mathrm{mL} / \mathrm{min})$ and $y$ is the dispersion oxygen feed rate $(\mathrm{L} / \mathrm{min})$. All nanostructured powders were produced at $x / y=5 / 5$, unless stated otherwise.

Powder compositions are identified by their $\mathrm{Ca}$ : dopant mass ratios. Product particles were characterized by nitrogen adsorption at $77 \mathrm{~K}$ in the relative pressure range $p / p_{0}=0.05-0.25$ (Micromeritics Tristar 3000, Micromeritics Instruments Corp., Norcross, GA) and by $\mathrm{x}$-ray diffraction (XRD, Bruker AXS D8 Advance diffractometer, Bruker Instruments, Billercia, MA). ${ }^{28}$ The particle diameter $d_{\mathrm{BET}}$ was calculated from the measured SSA by $d_{\mathrm{BET}}=6 /(\rho \cdot \mathrm{SSA})$, where $\rho$ is the solid particle density $\left[\mathrm{CaO}=3340 \mathrm{~kg} / \mathrm{m}^{3}, \mathrm{CaCO}_{3}\right.$ (calcite) $=2710 \mathrm{~kg} / \mathrm{m}^{3}$, $\left.\gamma-\mathrm{Fe}_{2} \mathrm{O}_{3}=4880 \mathrm{~kg} / \mathrm{m}^{3}, \mathrm{ZnO}=5600 \mathrm{~kg} / \mathrm{m}^{3}\right]$. The XRD patterns were measured directly after particle production. Crystallite sizes $\left(d_{\mathrm{XRD}}\right)$ were obtained by Rietveld refinement with TOPAS 4 (Bruker AXS) software using the fundamental parameter approach, calculated from the (100) plane at $2 \theta=31.8^{\circ}$ and the (002) plane ${ }^{29}$ at $2 \theta=34.4^{\circ}$ for $\mathrm{ZnO}$, and at the (200) plane at $2 \theta=37.4^{\circ}$ for $\mathrm{CaO}$. For calculation of cell constants, peak shifts resulting from sample preparation were eliminated ${ }^{24}$ by mixing product powder with metallic $\mathrm{Cu}$ (dendritic, $3 \mu \mathrm{m}, 99.7 \%$, Sigma-Aldrich) with known peak positions. TOPAS 4 was used to calculate the unit cell volume of $\mathrm{CaO}$ at the (220) plane at $2 \theta=53.9^{\circ}$.

In vitro solubility i.d.a. (after 15, 30, and $60 \mathrm{~min}$ ) and the total metal content of the powders were measured in triplicate ${ }^{21,28}$ by atomic absorption spectroscopy 
(SpectrAA-240FS, Agilent Technologies, Santa Clara, CA). The particles were deposited on a carbon foil supported on a copper grid for analysis using (scanning) transmission electron microscopy (S)TEM, performed on an FEI Tecnai F30 (Eindhoven, Netherlands; field emission gun, $300 \mathrm{kV}$ ). STEM images were recorded with a high angle annular dark field (HAADF) detector, while the presence of $\mathrm{Ca}$ and $\mathrm{Fe}$ at selected spots was detected by energy-dispersive $\mathrm{x}$-ray (EDX detector: EDAX) analysis. The total $\mathrm{Ca}(\mathrm{OH})_{2}$ and $\mathrm{CaCO}_{3}$ content of the powders was measured by thermogravimetric analysis (TGA, Netzsch STA 409 coupled with a Netzsch QMS 403C Aëolos mass spectrometer, NetzschGerätebau GmbH, Selb, Germany). Samples were heated to $1100{ }^{\circ} \mathrm{C}$ at $20 \mathrm{~K} / \mathrm{min}$ in an argon stream of $50 \mathrm{~mL} / \mathrm{min}$. Hydroxide and carbonate contents were determined from mass losses at $250-500{ }^{\circ} \mathrm{C}$ and $500-1000{ }^{\circ} \mathrm{C}$, respectively.

\section{RESULTS AND DISCUSSION}

\section{A. Iron-containing calcium oxide powders}

\section{The effect of particle size}

Powders were prepared at the nominal iron content $(\mathrm{Ca}: \mathrm{Fe}=125)$ according to the mass ratio of the RDA values of $\mathrm{Ca}$ and $\mathrm{Fe} .{ }^{27}$ Because of the significantly higher RDA requirement of $\mathrm{Ca}, \mathrm{Fe}$ is a dopant in the easily soluble $\mathrm{CaO}$ matrix. Figure 1 shows the $\mathrm{SSA}$ (squares) along with the calcium (circles) and iron solubilities (triangles) of these powders i.d.a. $(\mathrm{pH}=1)$ after $30 \mathrm{~min}$ as a function of precursor $/ \mathrm{O}_{2}$ FSP-feed ratio. Increasing this ratio results in hotter and longer flames ${ }^{30}$ leading to increased high temperature particle residence times. Furthermore, increasing that ratio increases the particle concentration in the flame

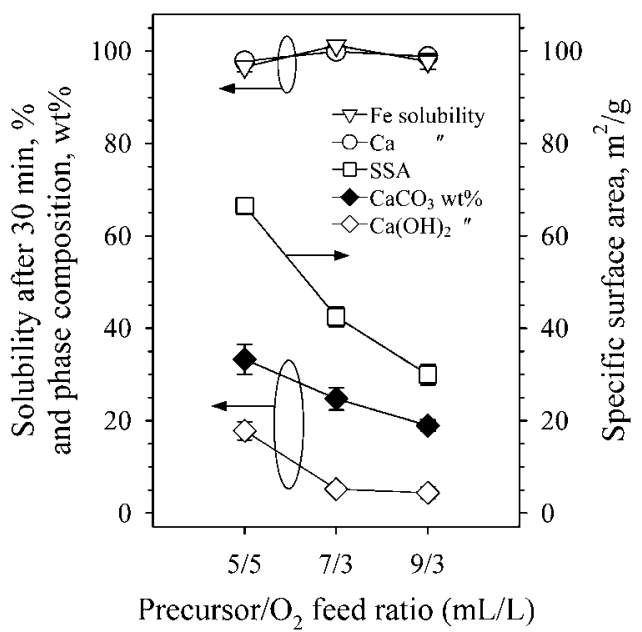

FIG. 1. SSA (squares), calcium hydroxide (open diamonds), and calcium carbonate contents (filled diamonds) as well as iron (triangles) and calcium (circles) solubilities of flame-made powders at the nominal RDA Ca:Fe mass ratio of 125 for males (19-50 years old) as function of the precursor $/ \mathrm{O}_{2}$ feed ratio to the FSP reactor. Increasing that ratio reduces the SSA along with hydroxide and carbonate contents but does not affect the Fe and $\mathrm{Ca}$ solubilities i.d.a. in $30 \mathrm{~min}$. leading to increased particle coagulation, sintering, and crystal growth that decrease the SSA from 67 to $30 \mathrm{~m}^{2} / \mathrm{g}$ (Fig. 1).

Here, the iron solubility i.d.a. is around $100 \%$, irrespective of SSA, indicating significant in vivo bioavailability. This is in contrast to pure iron oxide $\left(\gamma-\mathrm{Fe}_{2} \mathrm{O}_{3}\right)$ that exhibits lower solubility ${ }^{24}$ i.d.a. (74\% after $\left.30 \mathrm{~min}\right)$, despite having significantly higher $\mathrm{SSA}^{24}\left(185 \mathrm{~m}^{2} / \mathrm{g}\right)$. Co-oxidation of $\mathrm{Fe}$ with $\mathrm{Ca}$ during FSP results in mostly $\mathrm{CaO} / \mathrm{Fe}_{2} \mathrm{O}_{3}$ in solid solution, which improves iron dissolution. ${ }^{24}$

Figure 1 shows also that the $\mathrm{Ca}(\mathrm{OH})_{2}$ (open diamonds) and $\mathrm{CaCO}_{3}$ (filled diamonds) contents of these FSP-made powders decrease for increasing precursor/ $\mathrm{O}_{2}$ FSP-feed ratio. Calcium hydroxide is readily formed at ambient conditions since $\mathrm{CaO}$ has strong moisture affinity. ${ }^{31}$ Here, $\mathrm{Ca}(\mathrm{OH})_{2}$ is likely formed on the filter during powder collection. Calcium carbonate may be formed via two routes: in the presence of water (wet carbonation), $\mathrm{CaO}$ initially forms $\mathrm{Ca}(\mathrm{OH})_{2}$ and subsequently $\mathrm{CaCO}_{3}$ via dissolution of $\mathrm{CO}_{2}$ in a water layer around $\mathrm{Ca}(\mathrm{OH})_{2} .{ }^{32}$ This is a strong function of relative humidity ${ }^{32,33}$ and the dominant mechanism for $\mathrm{CaCO}_{3}$ formation at ambient conditions. ${ }^{31,33}$ In the absence of water, dry carbonation may take place ${ }^{31}$ without formation of intermediate $\mathrm{Ca}(\mathrm{OH})_{2}$, dominantly at temperatures above $400{ }^{\circ} \mathrm{C}$. During FSP synthesis of $\mathrm{CaO}$, dry carbonation may take place downstream of the flame where gas temperatures are high, while wet carbonation occurs during sample collection and powder storage at ambient conditions. For both carbonation mechanisms, smaller $\mathrm{CaO}$ particles react fast with $\mathrm{CO}_{2}$ and water because of their large exposed surface area. Most calcium carbonate here probably is formed by dry carbonation above the flame because TGA was done directly after synthesis, limiting room temperature carbonation.

As the precursor/ $\mathrm{O}_{2}$ FSP-feed ratio increases, the product $\mathrm{CaO}$ particles become larger. Higher precursor concentrations lead to larger particles ${ }^{25}$ with less surface available to react with $\mathrm{CO}_{2}$ whose diffusion into $\mathrm{CaO}$ is too slow for complete carbonation. ${ }^{34}$ This is in agreement with Lu et al. ${ }^{35}$ who observed the highest $\mathrm{CaCO}_{3}$ content for the smallest precursor/ $\mathrm{O}_{2}$ feed ratio for FSP-made Ca-containing powders. They observed $<10 \mathrm{wt} \% \mathrm{Ca}(\mathrm{OH})_{2}$, suggesting that all $\mathrm{CaCO}_{3}$ was formed during FSP synthesis. ${ }^{35}$ In contrast, Huber et al. ${ }^{36}$ observed that the highest carbonate fraction was obtained with the largest precursor/ $\mathrm{O}_{2}$ FSP-feed ratio. They had measured, however, the $\mathrm{CaCO}_{3}$ content of their powder hours to days after synthesis. This was verified here by repeating their experiments ${ }^{36}$ and aging such powders for up to 17 days.

The carbonate content here is significantly lower than previous reports. ${ }^{35,36}$ This can be attributed to the presence of large $\mathrm{CaO}$ particles made by droplet-to-particle conversion during FSP of the present ethanol/2-EHA-based precursor solutions (Sec. III. B). Such large particles were absent in powders made by FSP of xylene-based ${ }^{35,36}$ 
solvents. In addition, storage of such powders ${ }^{35,36}$ over time may have increased their carbonate content as well, as will be shown here. It should be noted that the Fe solubility i.d.a. after $30 \mathrm{~min}$ was significant despite these changes in phase composition (oxide, hydroxide, or carbonate) and the low SSA of these Ca-based nanopowders.

Figure 2 shows the XRD patterns of the FSP-made Fe-doped powders as a function of the precursor/ $\mathrm{O}_{2}$ FSP-feed ratio. For short flames $(5 / 5)$, the $\mathrm{Ca}(\mathrm{OH})_{2}$ and $\mathrm{CaCO}_{3}$ in these powders (Fig. 1) are amorphous. Increasing the FSP-feed ratio increases the crystalline fraction of $\mathrm{CaCO}_{3}$ (calcite) as seen by its peak intensity ${ }^{35}$ at $29.5^{\circ}$. For the $7 / 3$ and $9 / 3$ flames, the crystalline $\mathrm{CaCO}_{3}$ fraction is $10 \mathrm{wt} \%$ for both while the total $\mathrm{CaCO}_{3}$ fraction is $25 \mathrm{wt} \%$ and $19 \mathrm{wt} \%$, respectively (Fig. 1), indicating that a large part of $\mathrm{CaCO}_{3}$ is amorphous. In contrast, Lu et al. ${ }^{35}$ produced fully crystalline $\mathrm{CaCO}_{3}$ for the same FSP-feed ratios. Crystallization $^{36}$ of $\mathrm{CaCO}_{3}$ takes place around $310{ }^{\circ} \mathrm{C}$. Because of their ${ }^{35}$ short $(40 \mathrm{~cm})$ burner-to-filter distance (in contrast to $50-70 \mathrm{~cm}$ here) and their high enthalpy xylene-based precursor solution, it is likely that during particle synthesis, the temperature at their filter was sufficiently high to fully crystallize the $\mathrm{CaCO}_{3}$. The present $d_{\mathrm{XRD}}$ for $\mathrm{CaO}\left(\mathrm{CaCO}_{3}\right)$ made with the $7 / 3$ and $9 / 3$ flames is 68 (11) and 89 (11) nm, respectively. The "goodness-of-fit" figure of merit of the Rietveld refinement was low $(<1.3)$ and was not improved by applying a two-mode ${ }^{37}$ fit for $\mathrm{CaO}$, indicating that the $\mathrm{CaO}$ crystals are unimodal. As these powders fully dissolved i.d.a. within 30 min (Fig. 1), the crystallinity of $\mathrm{CaCO}_{3}$ does not affect $\mathrm{Fe}$ dissolution. Both SSA and phase composition of these flame-made

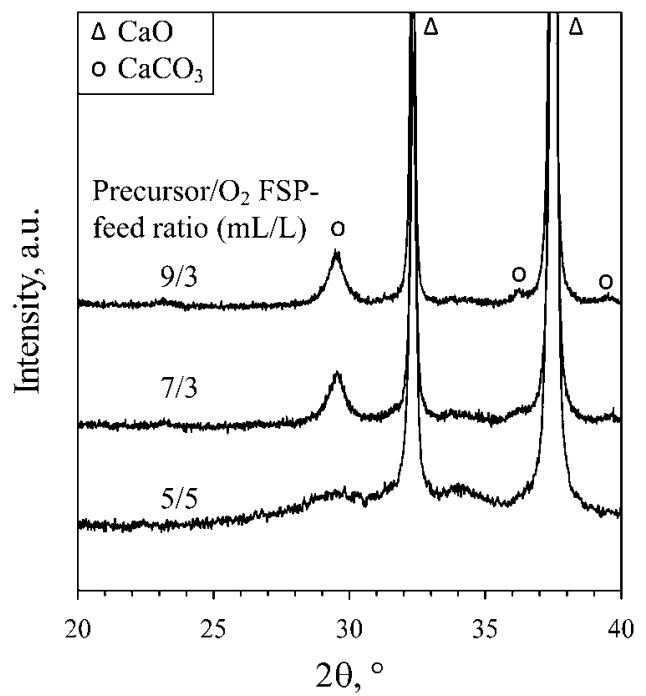

FIG. 2. XRD patterns of Ca-based powders having $\mathrm{Ca}: \mathrm{Fe}=125$ and produced at different precursor/ $\mathrm{O}_{2}$ FSP-feed ratios. Increasing that ratio from $5 / 5$ to $9 / 3$ increases the crystalline $\mathrm{CaCO}_{3}$ content of these mostly $\mathrm{CaO}$-containing as-prepared powders. The shortest and coolest flame (5/5), however, has the most $\mathrm{CaCO}_{3}$ and $\mathrm{Ca}(\mathrm{OH})_{2}$ (together $54 \mathrm{wt} \%$, Fig. 1), all amorphous.
$\mathrm{Ca} / \mathrm{Fe}$-containing nanopowders do not affect the high solubility of iron i.d.a. pointing out their potential as nutritional supplements.

\section{The effect of Fe-content}

Figure 3 shows the XRD patterns of $\mathrm{Ca} / \mathrm{Fe}$-containing powders with varying composition. Pure $\mathrm{Ca}$ forms mainly crystalline $\mathrm{CaO}$ while the small hump at $2 \theta=29.5^{\circ}$ indicates amorphous or nanocrystalline $\mathrm{CaCO}_{3}$. Increasing the iron content to $\mathrm{Ca}: \mathrm{Fe}=17.9$, no change is observed in the XRD patterns. For $\mathrm{Ca}: \mathrm{Fe}<17.9$, a mixed iron-calciumoxide $\mathrm{Ca}_{2} \mathrm{Fe}_{2} \mathrm{O}_{5}$ is formed ${ }^{24}$ as indicated by its main peak at $2 \theta=33.5^{\circ}$. This is in agreement with the binary phase diagram of $\mathrm{CaO}-\mathrm{Fe}_{2} \mathrm{O}_{3}$ : for $\mathrm{Ca}: \mathrm{Fe} \geq 0.7$ all iron is present as $\mathrm{Ca}_{2} \mathrm{Fe}_{2} \mathrm{O}_{5}$ in equilibrium with excess $\mathrm{CaO} .{ }^{38}$ Thus, the high $\mathrm{Ca}$ content of the powders prevents the formation of low-solubility ${ }^{24}$ crystalline iron oxides.

The iron and calcium solubility i.d.a. after 30 min was around $100 \%$ (not shown) for $\mathrm{Ca}: \mathrm{Fe} \geq 10.8$. This variation of iron content in the Ca-based powders ( $\mathrm{Ca}: \mathrm{Fe}=10.8-125)$ does not affect iron dissolution, allowing synthesis of highly soluble compounds tailor-made to specific population groups. For $\mathrm{Ca}: \mathrm{Fe}=5$, however, the iron solubility after 30 min decreased to $91 \%$ and to $87 \%$ for $\mathrm{Ca}: \mathrm{Fe}=3.6$. Previously, we had shown that iron solubility only decreases for very high iron contents $(\mathrm{Ca}: \mathrm{Fe}<0.7$ or molar $\mathrm{Ca}: \mathrm{Fe}<1) .{ }^{24}$ The low iron oxide content $(\mathrm{Ca}: \mathrm{Fe}=3.6)$ of powder made here at $x / y=5 / 5$ has a smaller crystalline iron fraction (33 wt\% crystalline $\mathrm{Ca}_{2} \mathrm{Fe}_{2} \mathrm{O}_{5}$ with $d_{\mathrm{XRD}}=24 \mathrm{~nm}$ ) and a lower SSA of $67 \mathrm{~m}^{2} / \mathrm{g}$ compared

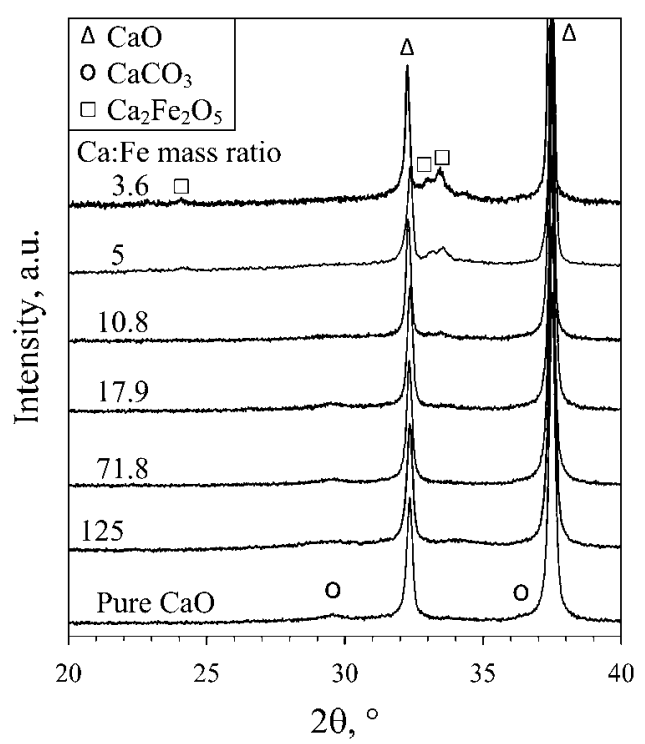

FIG. 3. XRD patterns of as-prepared Ca-based powders (5/5 flame) with varying iron content. For $\mathrm{Ca}: \mathrm{Fe} \leq 10.8$, peaks for crystalline $\mathrm{Ca}_{2} \mathrm{Fe}_{2} \mathrm{O}_{5}$ become visible while crystalline $\mathrm{CaCO}_{3}$ disappears. Upon aging, however, these powders become predominantly $\mathrm{CaCO}_{3}$ (Fig. 5). 
with those made in the past ${ }^{24}$ at $x / y=3 / 7(\mathrm{Ca}: \mathrm{Fe}=0.7$ containing $48 \mathrm{wt} \%$ crystalline $\mathrm{Ca}_{2} \mathrm{Fe}_{2} \mathrm{O}_{5}$ with $d_{\mathrm{XRD}}=27 \mathrm{~nm}$ and an SSA of $98 \mathrm{~m}^{2} / \mathrm{g}$ ). The $\mathrm{Ca}_{2} \mathrm{Fe}_{2} \mathrm{O}_{5}$ fraction and size may not be responsible for the reduced dissolution at $x / y=5 / 5$, as evidenced by the $100 \%$ calcium solubility i.d.a. already after $15 \mathrm{~min}$ (not shown). This indicates that in both powders, a fraction of low-solubility and perhaps nanocrystalline iron oxide is present that is not detected by XRD. Increasing the precursor $/ \mathrm{O}_{2}$ FSP-feed ratio increases the aerosol concentration and high temperature residence time $^{26}$ that promotes particle/crystal growth. ${ }^{30}$ For such high $\mathrm{Fe}$ contents $(\mathrm{Ca}: \mathrm{Fe} \leq 5)$, both crystallinity and SSA determine the dissolution rate.

Figure 4(a) shows an HAADF-STEM image of powders containing $\mathrm{Ca}: \mathrm{Fe}=5$ with the corresponding analysis of indicated sample areas 1-3 [Figs. 4(b)-4(d)] by EDX spectroscopy along with the nominal composition [Fig. 4(e)]. Analysis of area 1 [Fig. 4(c)] shows particles that are enriched with $\mathrm{Ca}$ : the ratio of $\mathrm{Ca}: \mathrm{Fe}$ in the EDX signal is stronger than that in the nominal composition [Fig. 4(e)]. For areas 2 and 3, however, the composition [Figs. 4(b) and $4(\mathrm{~d})$ ] appears close to the nominal one [Fig. 4(e)].
This difference in EDX between areas 1 and 2/3 indicates that not all iron is homogeneously distributed throughout the powder. This is in agreement with the XRD pattern (Fig. 3) where crystalline $\mathrm{Ca}_{2} \mathrm{Fe}_{2} \mathrm{O}_{5}$ was observed for that powder.

\section{The effect of storage}

Figure 5 shows the influence of storage time at ambient conditions on the XRD patterns of as-prepared powders with $\mathrm{Ca}$ :Fe mass ratio (a) 125 and (b) 3.6 and aged for 225 days. The as-prepared powder with $\mathrm{Ca}: \mathrm{Fe}=125$ [Fig. 5(a)] contains dominantly $\mathrm{CaO}$ with a fraction of amorphous $\mathrm{Ca}(\mathrm{OH})_{2}$ and $\mathrm{CaCO}_{3}$ (Fig. 1, 5/5 flame). After 225 days, that powder has changed completely to $\mathrm{CaCO}_{3}$ (circles in Fig. 5) as confirmed by TGA. Then mostly the thermodynamically stable calcite $\mathrm{CaCO}_{3}$ is present ${ }^{39}$ with a small fraction (2.8 wt\%) of metastable aragonite $\mathrm{CaCO}_{3}$ (filled circles) perhaps due to the presence of Fe. Increasing the iron content to $\mathrm{Ca}: \mathrm{Fe}=3.6$ [Fig. 5(b)] increases the aragonite fraction (12.8 wt\%), possibly originating from the initially present $\mathrm{Ca}_{2} \mathrm{Fe}_{2} \mathrm{O}_{5}$.

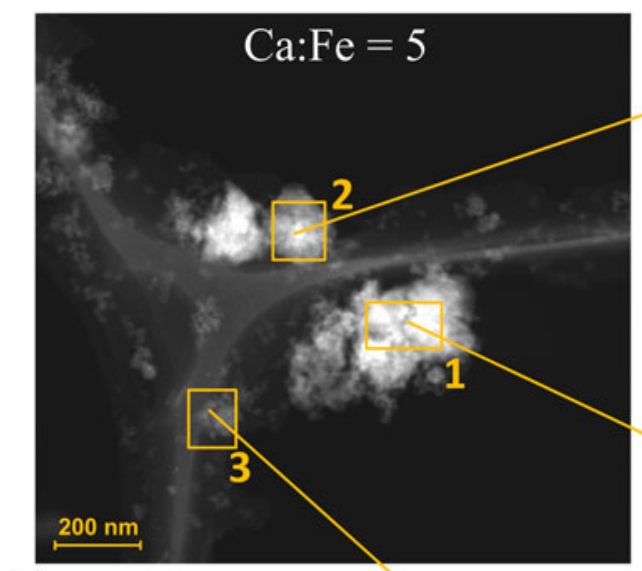

(a)

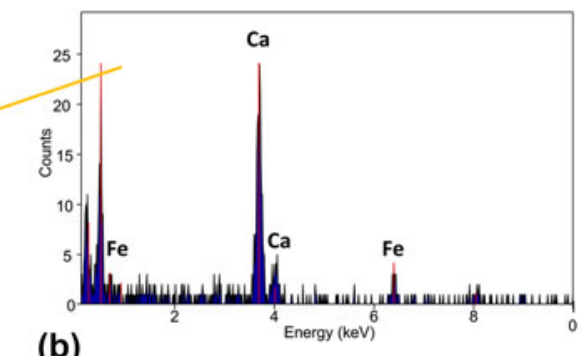

(b)
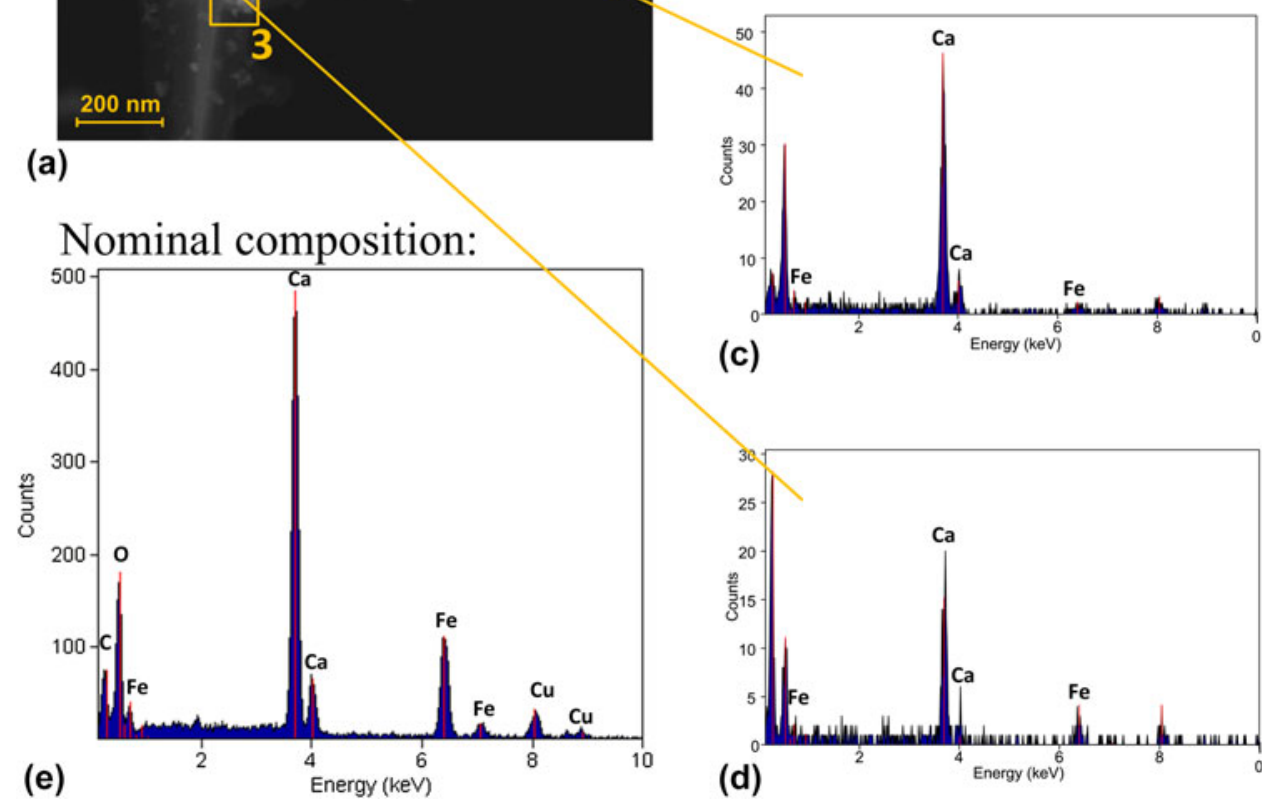

(d)

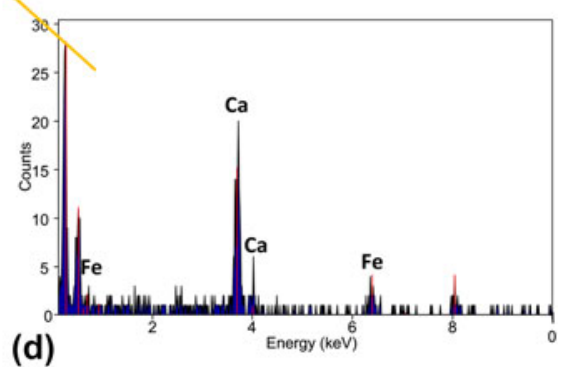

FIG. 4. STEM image (a) of powders containing $\mathrm{Ca}: \mathrm{Fe}=5$ with EDX analysis at indicated positions. Area 1 is enriched with calcium, whereas areas 2 and 3 seem close to the nominal composition of iron and calcium. This demonstrates that iron is rather inhomogeneously distributed inside the $\mathrm{CaO}$ matrix, as supported by XRD (Fig. 3) where crystalline $\mathrm{Ca}_{2} \mathrm{Fe}_{2} \mathrm{O}_{5}$ was found. 


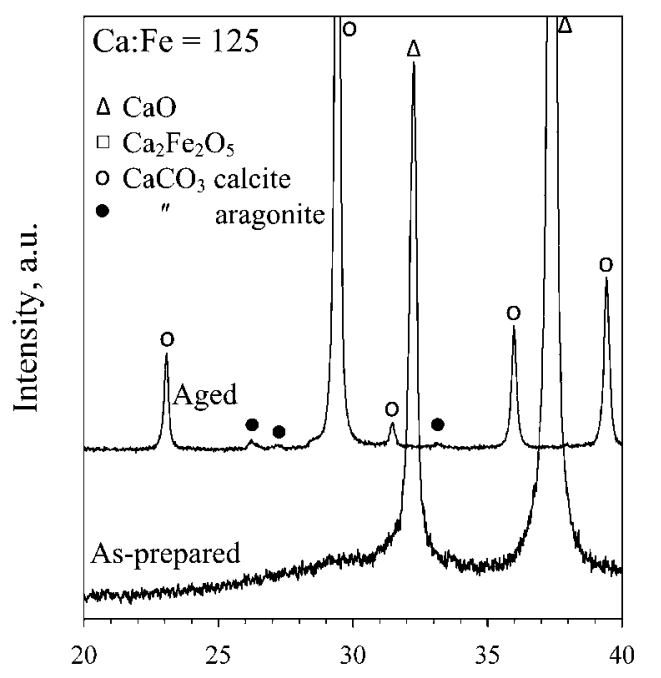

(a)

$20,^{\circ}$

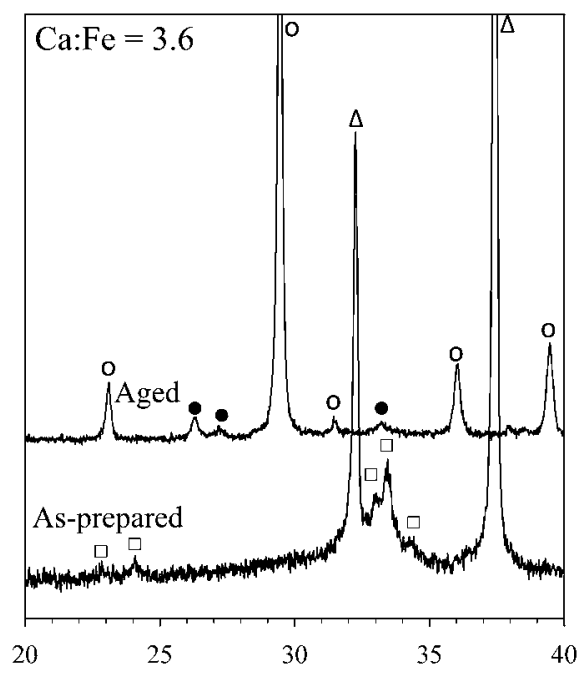

$2 \theta$,

FIG. 5. XRD patterns of CaO-based powders with Ca:Fe mass ratio (a) 125 and (b) 3.6, as-prepared and aged for 225 days under ambient conditions The as-prepared materials consist mainly of crystalline $\mathrm{CaO}$ with $\mathrm{Ca}_{2} \mathrm{Fe}_{2} \mathrm{O}_{5}$. Upon storage, both compounds are converted completely to CaCO (as confirmed by TGA) by the influence of humidity and $\mathrm{CO}_{2}$ in the atmosphere. Mostly thermodynamically favorable calcite is formed while the presence of iron likely induces formation of metastable aragonite.

The SSA is $67 \mathrm{~m}^{2} / \mathrm{g}$ for both as-prepared calciumbased powders $(\mathrm{Ca}: \mathrm{Fe}=125$ and 3.6). Upon 225 days storage, their SSA decreased to 19 and $44 \mathrm{~m}^{2} / \mathrm{g}$, respectively. The increased iron fraction apparently inhibited SSA reduction by hydration and carbonation. Despite these strong changes in SSA and crystal structure, the iron solubility i.d.a. did not decrease significantly ${ }^{24}: 96 \%$ and $84 \%$ after 225 days aging of powders containing $\mathrm{Ca}: \mathrm{Fe}=125$ and 3.6, respectively, compared with $97 \%$ and $87 \%$ for the as-prepared compounds. Quite likely iron is incorporated in the $\mathrm{CaCO}_{3}$ lattice. ${ }^{40}$ This favors $\mathrm{Fe}$ dissolution because of the lower lattice energy of $\mathrm{CaCO}_{3}(2804 \mathrm{~kJ} / \mathrm{mol})^{41}$ compared with $\mathrm{Fe}_{2} \mathrm{O}_{3}(14,309 \mathrm{~kJ} / \mathrm{mol})^{41}$ or $\mathrm{Ca}_{2} \mathrm{Fe}_{2} \mathrm{O}_{5}$ $(7046 \mathrm{~kJ} / \mathrm{mol}){ }^{42}$

\section{B. Zinc/calcium oxides}

Figure 6 shows the XRD patterns of FSP-made powders with varying $\mathrm{Ca}: \mathrm{Zn}$ mass ratio. Powders with $\mathrm{Ca}: \mathrm{Zn}=91$ closely correspond to the RDA values $(1000 \mathrm{mg}$ and $11 \mathrm{mg}$ for calcium and zinc, respectively). ${ }^{27}$ For low $\mathrm{Zn}$ contents $(\mathrm{Ca}: \mathrm{Zn}>2)$, the XRD patterns resemble those of crystalline $\mathrm{CaO}$ while the small hump at $2 \theta=29.5^{\circ}$ indicates amorphous $\mathrm{CaCO}_{3}$. Separate $\mathrm{ZnO}$ is not detected until $\mathrm{Ca}: \mathrm{Zn}=1$, possibly because $\mathrm{ZnO}$ is largely amorphous or nanocrystalline $\left(d_{\mathrm{XRD}} \leq 3.4 \mathrm{~nm}\right){ }^{43}$ At $\mathrm{Ca}: \mathrm{Zn}=0.05-1$, both $\mathrm{CaO}$ and $\mathrm{ZnO}$ crystals coexist. The main peak of $\mathrm{CaO}$ is visible at $2 \theta=37.4^{\circ}$ for $\mathrm{Ca}: \mathrm{Zn}=0.05$ (as indicated by an arrow in Fig. 6) while no mixed oxide is formed.

Figure 7 shows the $d_{\mathrm{BET}}$ and $d_{\mathrm{XRD}}$ of the above powders. Their $d_{\mathrm{BET}}$ changes from 15 (pure $\mathrm{ZnO}$ ) to $28 \mathrm{~nm}$ (pure $\mathrm{CaO}$ ) with a minimum of $12 \mathrm{~nm}$ at $\mathrm{Ca}: \mathrm{Zn}=0.1$.

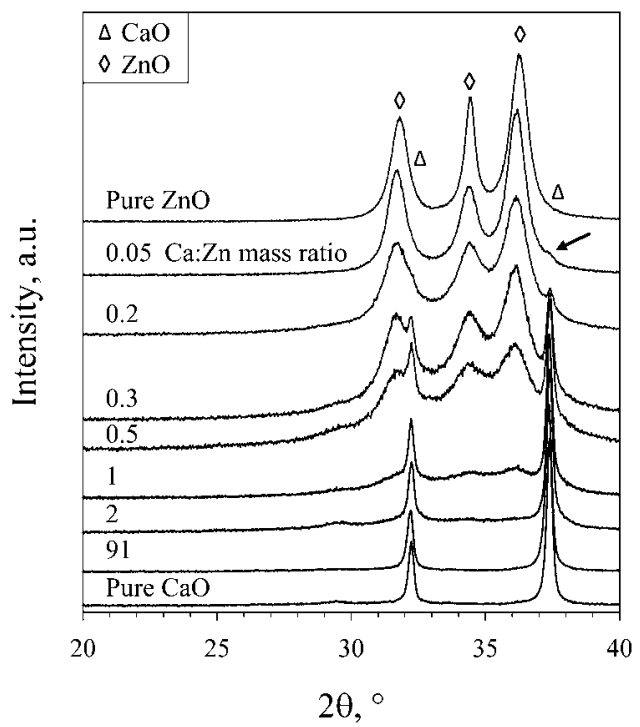

FIG. 6. XRD patterns of FSP-made powders (5/5 flame) with varying $\mathrm{Ca}: \mathrm{Zn}$ mass ratio. For $\mathrm{Ca}: \mathrm{Zn} \leq 1$, the XRD patterns of $\mathrm{ZnO}$ and $\mathrm{CaO}$ coexist. Crystalline $\mathrm{CaO}$ is still detected at $\mathrm{Ca}: \mathrm{Zn}=0.05$ (small peak around $37.4^{\circ}$ as indicated by the arrow). No new mixed $\mathrm{Ca}-\mathrm{Zn}$ oxide appears to be formed.

The $d_{\mathrm{XRD}}$ corresponding to the (002) plane of $\mathrm{ZnO}$ decreases from 20 to $5 \mathrm{~nm}$ from pure $\mathrm{ZnO}$ to $\mathrm{Ca}: \mathrm{Zn}=0.5$, whereas the $d_{\mathrm{XRD}}$ of their (100) plane decreases as well from 14 to $5 \mathrm{~nm}$. For $\mathrm{Zn}$-rich materials $(\mathrm{Ca}: \mathrm{Zn} \leq 0.1)$, the $d_{\mathrm{BET}}$ corresponds well to an average $d_{\mathrm{XRD}}$ of the (100) and (002) planes. For Ca: $\mathrm{Zn}=0.1-0.5$, the $d_{\mathrm{XRD}}$ of the two $\mathrm{ZnO}$ planes are identical indicative of compact (spherical-like) $\mathrm{ZnO}$ crystals, similar ${ }^{29}$ to Li-doped $\mathrm{ZnO}$. At these compositions, the $d_{\mathrm{BET}}$ seems to correspond well to 
an average of the $\mathrm{CaO}$ and $\mathrm{ZnO}$ crystal sizes, indicating monocrystalline powders.

The $\mathrm{ZnO}$ crystal size decreases with increasing $\mathrm{CaO}$ content similar to $\mathrm{SiO}_{2}$-doping of flame-made $\mathrm{ZnO}$ quantum dots, ${ }^{43}$ possibly as a result of slower sintering of mixed oxides compared with pure oxides. ${ }^{44}$ In the case of Si-doping and comparing ionic radii ${ }^{45}$ (based on a coordination number of 6$)$, the smaller $\mathrm{Si}^{4+}(0.40 \AA)$ compared with $\mathrm{Zn}^{2+}(0.74 \AA)$ can enter the $\mathrm{ZnO}$ lattice interstitially suppressing $\mathrm{ZnO}$ crystal growth. ${ }^{46}$ The $\mathrm{Ca}^{2+}$ ionic radius $(1.00 \AA)$ is larger than $\mathrm{Zn}^{2+}$ and is more likely to substitute $\mathrm{Zn}^{2+}$ in the crystal. This may decrease the $\mathrm{ZnO}$

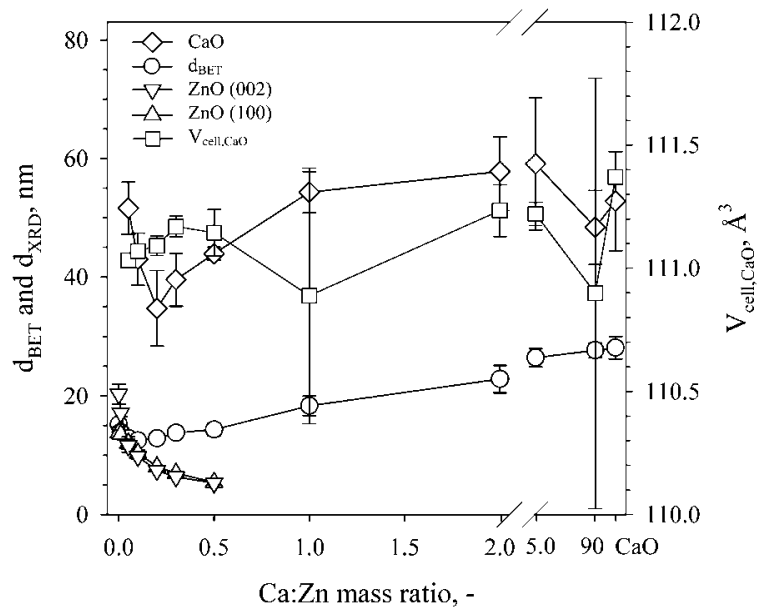

FIG. 7. $\mathrm{CaO}$ unit cell volume (squares), crystal size of $\mathrm{ZnO}$ (triangles and inverted triangles) and $\mathrm{CaO}$ (diamonds), and BET-equivalent diameter (circles) as function of the $\mathrm{Ca}: \mathrm{Zn}$ mass ratio. The $\mathrm{CaO}$ crystal size is larger than the BET-equivalent diameter quite likely due to the formation of nanosized amorphous $\mathrm{Ca}(\mathrm{OH})_{2}$ and $\mathrm{CaCO}_{3}$ particles that coexist with the larger $\mathrm{CaO}$ crystals. For $\mathrm{Ca}: \mathrm{Zn} \leq 0.1$, the two $\mathrm{ZnO}$ crystal sizes are in good agreement with the BET-equivalent diameter. The $\mathrm{CaO}$ unit cell volume is hardly affected by the $\mathrm{Zn}$ addition. crystal size, similar to doping of $\mathrm{ZnO}$ with $\mathrm{Cd}^{2+}(0.95 \AA)$ by high-pressure solution growth ${ }^{47}$ and doping ${ }^{48}$ of $\mathrm{TiO}_{2}$ with $\mathrm{Al}^{3+}$ during its aerosol synthesis in hot wall reactors.

The $\mathrm{CaO}$ crystal size is significantly larger than the BET-average diameter for all compositions. To verify whether this is because the $\mathrm{CaO}$ crystals are bimodally distributed, the XRD patterns were fitted using the Rietveld refinement with two crystal modes. ${ }^{37}$ The goodness-of-fit figure of merit did not decrease significantly compared with a one-mode fit, indicating that both $\mathrm{ZnO}$ and $\mathrm{CaO}$ form unimodal crystals. A possible explanation for the larger $\mathrm{CaO}$ crystal size compared with $d_{\mathrm{BET}}$ is the formation of nanosize amorphous $\mathrm{CaCO}_{3}$ as seen by TEM [Fig. 8(a)] and confirmed by TGA. The TEM image of mixed $\mathrm{Ca} / \mathrm{Zn}$ oxide with Ca:Zn $=0.2$ [Fig. 8(b)], however, did not show any large particles even though the $d_{\mathrm{XRD}}$ of $\mathrm{CaO}$ is larger than the average $d_{\mathrm{BET}}$ (Fig. 7): it is quite likely that there are only very few of them. The $\mathrm{ZnO}$ does not form a bimodal size distribution since even if large $\mathrm{ZnO}$ crystals had been formed, these would decompose rapidly above $1700{ }^{\circ} \mathrm{C}$ and nanosized $\mathrm{ZnO}$ crystals would form from the gas phase at lower temperatures. ${ }^{49}$

The unit cell volume of $\mathrm{CaO}$ was calculated (Fig. 7, squares) to explore the formation of $\mathrm{CaO}-\mathrm{ZnO}$ solid solutions. This volume varies around $111 \AA^{3}$ (corresponding to a unit cell length of $0.48 \mathrm{~nm}$ ) so a clear trend is not visible. Incorporation of $\mathrm{Zn}^{2+}$ into the $\mathrm{CaO}$ lattice is expected to decrease the $\mathrm{CaO}$ unit cell volume because of the smaller radius of $\mathrm{Zn}^{2+}$ compared with $\mathrm{Ca}^{2+}$, as shown for $\mathrm{Mg}^{2+}$ doping. ${ }^{50}$ The absence of such a trend does not necessarily mean that $\mathrm{Zn}^{2+}$ is not dissolved in $\mathrm{CaO}$. Substitution of $\mathrm{Zn}^{2+}$ for $\mathrm{Ca}^{2+}$ in $\mathrm{CaCO}_{3}$ (calcite) is energetically favorable ${ }^{40}$ and was found experimentally ${ }^{51}$ to occur at low $(<1000 \mathrm{ppm} \mathrm{Zn})$ concentrations. Incorporation of $\mathrm{Zn}^{2+}$ in $\mathrm{CaO}$ or $\mathrm{CaCO}_{3}$ reduces the $\mathrm{ZnO}$ lattice energy ${ }^{42}$ and thus the average $\mathrm{Zn}-\mathrm{O}$

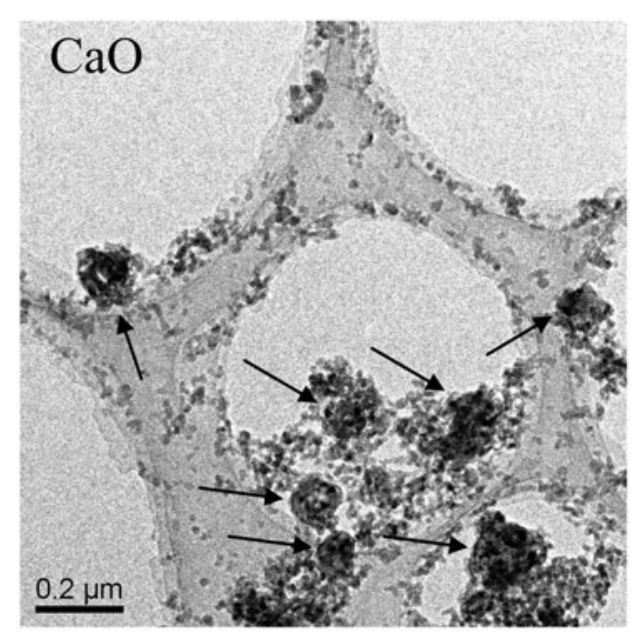

(a)

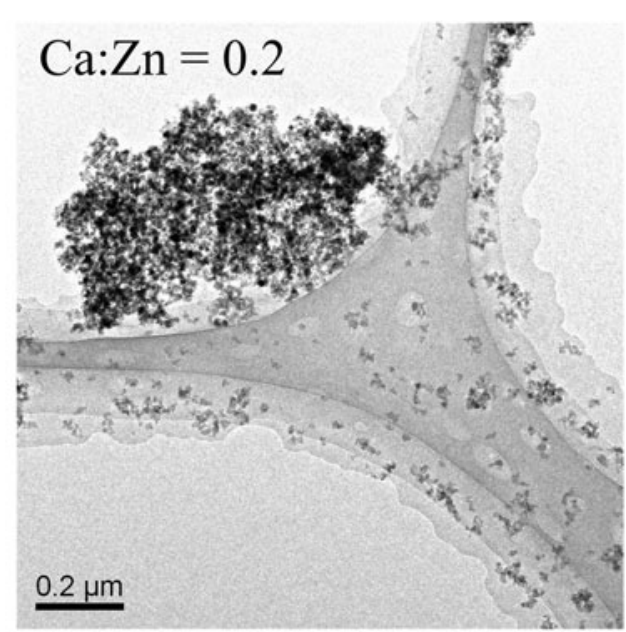

(b)

FIG. 8. Typical TEM images of (a) pure $\mathrm{CaO}$ and (b) $\mathrm{Ca} / \mathrm{Zn}$ oxide containing $\mathrm{Ca}: \mathrm{Zn}$ mass ratio of 0.2. Pure $\mathrm{CaO}$ forms a bimodal particle size distribution since large particles (indicated by the arrows) coexist with nanosized ones. For Ca: $\mathrm{Zn}=0.2$, a more homogeneous distribution is found. 
bond strength, as the lattice energy ${ }^{41}$ of $\mathrm{CaO}\left(3^{\prime} 414 \mathrm{~kJ} / \mathrm{mol}\right)$ and $\mathrm{CaCO}_{3}\left(2^{\prime} 804 \mathrm{~kJ} / \mathrm{mol}\right)$ is lower than that of $\mathrm{ZnO}$ $\left(4^{\prime} 142 \mathrm{~kJ} / \mathrm{mol}\right)$. The solubility i.d.a. of pure $\mathrm{ZnO}$ $\left(15-25 \mathrm{~m}^{2} / \mathrm{g}\right)$, however, is already very $\mathrm{high}^{28}(>95 \%)$ thus a solid solution cannot further improve $\mathrm{Zn}$ dissolution at this $\mathrm{pH}$. Here also the $\mathrm{Zn}$ and $\mathrm{Ca}$ solubilities i.d.a. after 30 min were already $100 \%$, irrespective of composition (not shown). This shows that the composition of $\mathrm{Ca} / \mathrm{Zn}$ containing powders can be tuned freely without sacrificing product performance.

\section{Multicomponent doping of calcium oxide}

Along with $\mathrm{Fe}$ and $\mathrm{Zn}, \mathrm{Cu}$ and $\mathrm{Mn}$ are also essential trace minerals for humans. These elements are present in most multimineral supplement tablets. ${ }^{12}$ In rodent studies, Mn deficiency was associated with skeletal abnormalities as well as distortion in carbohydrate and lipid metabolism. ${ }^{52}$ Copper deficiency is associated with anemia, neutropenia, and osteoporosis. ${ }^{52}$ Because of their importance in human nutrition, we also produced $\mathrm{CaO}$ with stoichiometric amounts of copper and manganese at standard FSP conditions; their solubility i.d.a. after $30 \mathrm{~min}$ is shown in Fig. 9. The dopant amounts are given above the figure and are based on the respective RDA/AI values of the individual metals for males $19-50$ years [Ca $(1000 \mathrm{mg}), \mathrm{Fe}(8 \mathrm{mg})$, $\mathrm{Zn}(11 \mathrm{mg}), \mathrm{Mn}(2.3 \mathrm{mg})$, and $\mathrm{Cu}(0.9 \mathrm{mg})] \cdot{ }^{27}$ Here, the solubility of all elements is again high (above 94\%) demonstrating that different trace elements and their mixtures at RDA-relevant compositions incorporated in $\mathrm{CaO}$ matrices can be produced in one step by scalable flame spray pyrolysis. Even a mixture of $\mathrm{Fe}$ and $\mathrm{Zn}$ may be incorporated in the $\mathrm{CaO}$ with high solubility i.d.a. without affecting each

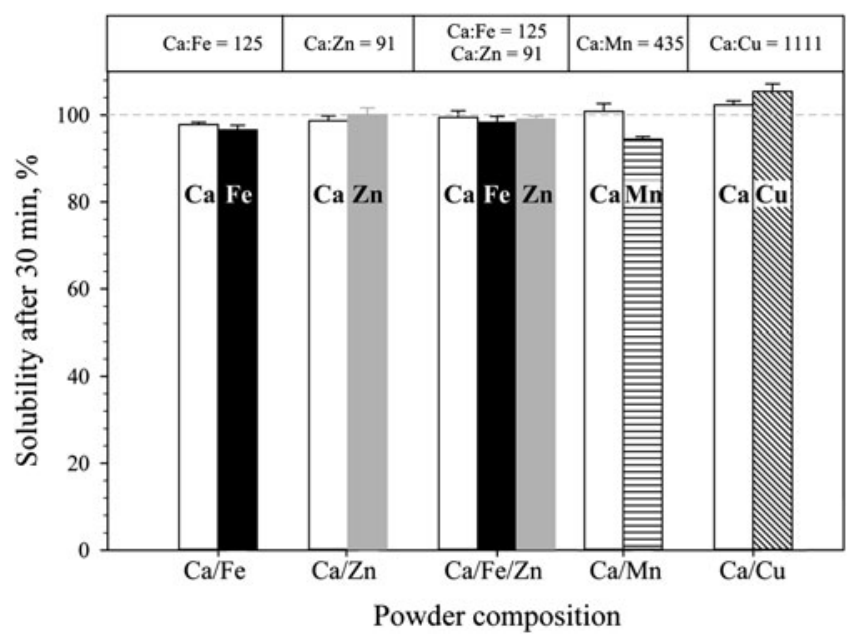

FIG. 9. Solubility i.d.a. after $30 \mathrm{~min}$ for the various dopants in the $\mathrm{CaO}$ matrix. The Ca:dopant mass ratios (above the figure) are based on the RDA values of each mineral. Apart from iron, also zinc, copper and manganese, or even combinations of elements may be incorporated in the one-step FSP process. For all elements, almost complete dissolution is obtained after $30 \mathrm{~min}$, suggesting these compounds should have high in vivo bioavailability. other's dissolution (Fig. 9). In single meal studies, it has been shown that high concentrations of calcium can negatively influence iron absorption. However, in long-term studies, this effect is often less pronounced or absent (for a review see Lynch $^{53}$ ). Mineral interactions can be observed in conventional supplements ${ }^{8,13}$ and are thus not specific for nanostructured compounds.

\section{CONCLUSIONS}

Nanostructured Ca-based supplements with nutritionally relevant amounts of iron and/or zinc were prepared by scalable, one-step flame aerosol technology. Their complete dissolution i.d.a. after 30 min suggests that these nanomaterials should have high in vivo bioavailability. The particle size and composition (oxide/carbonate, mineral composition) do not affect solubility i.d.a. for $\mathrm{Ca} / \mathrm{Fe}$ and $\mathrm{Ca} / \mathrm{Zn}$ oxides. Matrix encapsulation of $\mathrm{Fe}$ by $\mathrm{CaO}$ results in a mixed oxide $\mathrm{Ca}_{2} \mathrm{Fe}_{2} \mathrm{O}_{5}$ coexisting with mainly crystalline $\mathrm{CaO}$ and amorphous calcium hydroxide and carbonate. For $\mathrm{Ca}: \mathrm{Fe} \geq 10.8$, the solubility i.d.a. after 30 min does not depend on crystallinity and SSA. Storage for 225 days under ambient conditions converted the powders to crystalline $\mathrm{CaCO}_{3}$ that hardly affected the Fe solubility. The large amounts of calcium prevent formation of separate, low-solubility iron oxide.

No mixed $\mathrm{Ca}-\mathrm{Zn}$ oxide was observed and no change in the $\mathrm{CaO}$ unit cell volume was measured by $\mathrm{Zn}$ doping. Flexibility of the process is demonstrated by variation of powder composition. Also other trace elements such as $\mathrm{Mn}$ and $\mathrm{Cu}$ may be incorporated, with high solubility i.d.a. and therefore potentially high bioavailability. Thus flame-made nanostructured compounds may offer a promising approach to manufacture tailor-made compounds for supplementation. Since the powders are homogeneous and do not segregate even when multiple phases are present, they may also facilitate the production of mineral supplement tablets and capsules.

\section{ACKNOWLEDGMENTS}

This work was supported by ETH Research Grant ETH-06 10-1. (S)TEM investigations were carried out at the Electron Microscopy ETH Zurich.

\section{REFERENCES}

1. L. Allen, B. De Benoist, O. Dary, and R.F. Hurrell: Guidelines on Food Fortification with Micronutrients (World Health Org., Geneva, 2006).

2. WHO: Worldwide Prevalence of Anaemia 1993-2005: WHO Global Database on Anaemia (World Health Org., Geneva, 2008).

3. M.B. Zimmermann and R.F. Hurrell: Nutritional iron deficiency. Lancet 370, 511 (2007).

4. A.L.M. Heath and S.J. Fairweather-Tait: Clinical implications of changes in the modern diet: Iron intake, absorption and status. Best Pract. Res. Clin. Haematol. 15, 225 (2002). 
5. T.O. Scholl: Iron status during pregnancy: Setting the stage for mother and infant. Am. J. Clin. Nutr. 81, 1218S (2004).

6. J.D. Haas and T.I.V. Brownlie: Iron deficiency and reduced work capacity: A critical review of the research to determine a causal relationship. J. Nutr. 131, 676S (2001).

7. C. Hotz and K. H. Brown (eds): Assessment of the risk of zinc deficiency in populations and options for its control. Food Nutr. Bull. 25, S91 (2004).

8. F.T. Wieringa, J. Berger, M.A. Dijkhuizen, A. Hidayat, N.X. Ninh, B. Utomo, E. Wasantwisut, and P. Winichagoon: Combined iron and zinc supplementation in infants improved iron and zinc status, but interactions reduced efficacy in a multicountry trial in southeast Asia. J. Nutr. 137, 466 (2007).

9. N. De Jong, M.C. Ocke, H.A.C. Branderhorst, and R. Friele: Demographic and lifestyle characteristics of functional food consumers and dietary supplement users. Br. J. Nutr. 89, 273 (2003).

10. P. Marques-Vidal, A. Pecoud, D. Hayoz, F. Paccaud, V. Mooser, G. Waeber, and P. Vollenweider: Prevalence and characteristics of vitamin or dietary supplement users in Lausanne, Switzerland: the CoLaus study. Eur. J. Clin. Nutr. 63, 273 (2009).

11. R.L. Bailey, J.J. Gahche, C.V. Lentino, J.T. Dwyer, J.S. Engel, P.R. Thomas, J.M. Betz, C.T. Sempos, and M.F. Picciano: Dietary supplement use in the United States, 2003-2006. J. Nutr. 141, 261 (2011).

12. G.P. Webb: Dietary Supplements and Functional Foods, $2^{\text {nd }}$ ed. (Wiley-Blackwell, Chichester, 2011).

13. S.J. Fairweather-Tait and B. Teucher: Iron and calcium bioavailability of fortified foods and dietary supplements. Nutr. Rev. $\mathbf{6 0}, 360$ (2002).

14. European Parliament and the Council of the European Union: Directive 2002/46/EC of the European Parliament and the Council of 10 June 2002 (Official Journal of the European Communities, Luxemburg, 12.7.2002, L.183, 2002), p. 51-57.

15. A. Flynn and K. Cashman: Chapter 2: Calcium, in The Mineral Fortification of Foods, edited by R.F. Hurrell (Leatherhead Publishing, Surrey, UK, 1999), p. 18-53.

16. N. Harnby, M.F. Edwards, and A.W. Nienow: Mixing in the Process Industries (Butterworth-Heinemann, Oxford, 1997).

17. D.G. Wei, R. Dave, and R. Pfeffer: Mixing and characterization of nanosized powders: An assessment of different techniques. J. Nanopart. Res. 4, 21 (2002).

18. D.D. Miller: Food nanotechnology: New leverage against iron deficiency. Nat. Nanotechnol. 5, 318 (2010).

19. M.B. Zimmermann and F.M. Hilty: Nanocompounds of iron and zinc: Their potential in nutrition. Nanoscale 3, 2390 (2011).

20. F.M. Hilty, M. Arnold, M. Hilbe, A. Teleki, J.T.N. Knijnenburg, F. Ehrensperger, R.F. Hurrell, S.E. Pratsinis, W. Langhans, and M.B. Zimmermann: Iron from nanocompounds containing iron and zinc is highly bioavailable in rats without tissue accumulation. Nat. Nanotechnol. 5, 374 (2010).

21. J.H. Swain, S.M. Newman, and J.R. Hunt: Bioavailability of elemental iron powders to rats is less than bakery-grade ferrous sulfate and predicted by iron solubility and particle surface area. J. Nutr. 133, 3546-3552 (2003).

22. I. Motzok, M.D. Pennell, M.I. Davies, and H.U. Ross: Effect of particle size on the biological availability of reduced iron. J. Assoc. Off. Anal. Chem. 58, 99 (1975).

23. F. Rohner, F.O. Ernst, M. Arnold, M. Hilbe, R. Biebinger, F. Ehrensperger, S.E. Pratsinis, W. Langhans, R.F. Hurrell, and M.B. Zimmermann: Synthesis, characterization, and bioavailability in rats of ferric phosphate nanoparticles. J. Nutr. 137, 614 (2007).

24. F.M. Hilty, J.T.N. Knijnenburg, A. Teleki, F. Krumeich, R.F. Hurrell, S.E. Pratsinis, and M.B. Zimmermann: Incorporation of $\mathrm{Mg}$ and $\mathrm{Ca}$ into nanostructured $\mathrm{Fe}_{2} \mathrm{O}_{3}$ improves Fe solubility in dilute acid and sensory characteristics in foods. J. Food Sci. 76, N2 (2011).
25. L. Madler, H.K. Kammler, R. Mueller, and S.E. Pratsinis: Controlled synthesis of nanostructured particles by flame spray pyrolysis. J. Aerosol Sci. 33, 369 (2002).

26. R. Strobel and S.E. Pratsinis: Flame aerosol synthesis of smart nanostructured materials. J. Mater. Chem. 17, 4743 (2007).

27. J.J. Otten, J.P. Hellwig, and L.D. Mayers: Dietary Reference Intakes: The Essential Guide to Nutrient Requirements (Institute of Medicine of the National Academies, N.W. Washington DC, 2006).

28. F.M. Hilty, A. Teleki, F. Krumeich, R. Buchel, R.F. Hurrell, S.E. Pratsinis, and M.B. Zimmermann: Development and optimization of iron- and zinc-containing nanostructured powders for nutritional applications. Nanotechnology 20, 475101 (2009).

29. M.J. Height, L. Madler, S.E. Pratsinis, and F. Krumeich: Nanorods of $\mathrm{ZnO}$ made by flame spray pyrolysis. Chem. Mater. 18, 572 (2006).

30. A. Camenzind, R. Strobel, and S.E. Pratsinis: Cubic or monoclinic $\mathrm{Y}_{2} \mathrm{O}_{3}: \mathrm{Eu}^{3+}$ nanoparticles by one step flame spray pyrolysis. Chem. Phys. Lett. 415, 193 (2005).

31. R.S. Boynton: Chemistry and Technology of Lime and Limestone, $1^{\text {st }}$ ed. (John Wiley \& Sons, New York, 1966).

32. S.M. Shih, C.S. Ho, Y.S. Song, and J.P. Lin: Kinetics of the reaction of $\mathrm{Ca}(\mathrm{OH})_{2}$ with $\mathrm{CO}_{2}$ at low temperature. Ind. Eng. Chem. Res. 38, 1316 (1999).

33. R.M. Dheilly, J. Tudo, and M. Queneudec: Influence of climatic conditions on the carbonation of quicklime. J. Mater. Eng. Perform. 7, 789 (1998).

34. A. Silaban and D.P. Harrison: High temperature capture of carbon dioxide: Characteristics of the reversible reaction between $\mathrm{CaO}(\mathrm{s})$ and $\mathrm{CO}_{2}$ (g). Chem. Eng. Commun. 137, 177 (1995).

35. H. Lu, P.G. Smirniotis, F.O. Ernst, and S.E. Pratsinis: Nanostructured Ca-based sorbents with high $\mathrm{CO}_{2}$ uptake efficiency. Chem. Eng. Sci. 64, 1936 (2009).

36. M. Huber, W.J. Stark, S. Loher, M. Maciejewski, F. Krumeich, and A. Baiker: Flame synthesis of calcium carbonate nanoparticles. Chem. Commun. 648-650 (2005).

37. T. Rudin, K. Wegner, and S.E. Pratsinis: Uniform nanoparticles by flame-assisted spray pyrolysis (FASP) of low cost precursors. J. Nanopart. Res. 13, 2715 (2011).

38. B. Bergman: Solid-state reactions between $\mathrm{CaO}$ powder and $\mathrm{Fe}_{2} \mathrm{O}_{3}$. J. Am. Ceram. Soc. 69, 608 (1986).

39. A.V. Radha, T.Z. Forbes, C.E. Killian, P. Gilbert, and A. Navrotsky: Transformation and crystallization energetics of synthetic and biogenic amorphous calcium carbonate. Proc. Natl. Acad. Sci. USA 107, 16438 (2010).

40. D.K. Fisler, J.D. Gale, and R.T. Cygan: A shell model for the simulation of rhombohedral carbonate minerals and their point defects. Am. Mineral. 85, 217 (2000).

41. W.M. Haynes: CRC Handbook of Chemistry and Physics, $92^{\text {nd }}$ ed. (CRC Press/Taylor and Francis, Boca Raton, FL, 2012).

42. C.H. Yoder and N.J. Flora: Geochemical applications of the simple salt approximation to the lattice energies of complex materials. Am. Mineral. 90, 488 (2005).

43. L. Madler, W.J. Stark, and S.E. Pratsinis: Rapid synthesis of stable ZnO quantum dots. J. Appl. Phys. 92, 6537 (2002).

44. S. Vemury and S.E. Pratsinis: Dopants in flame synthesis of titania. J. Am. Ceram. Soc. 78, 2984 (1995).

45. R.D. Shannon: Revised effective ionic radii and systematic studies of interatomic distances in halides and chalcogenides. Acta Crystallogr., Sect. A: Found. Crystallogr. 32, 751 (1976).

46. T. Tani, L. Madler, and S.E. Pratsinis: Synthesis of zinc oxide/silica composite nanoparticles by flame spray pyrolysis. J. Mater. Sci. 37, 4627 (2002).

47. M. Ghosh and A.K. Raychaudhuri: Structure and optical properties of Cd-substituted $\mathrm{ZnO}\left(\mathrm{Zn}_{1-\mathrm{x}} \mathrm{Cd}_{\mathrm{x}} \mathrm{O}\right)$ nanostructures synthesized by the high-pressure solution route. Nanotechnology 18,115618 (2007). 
48. M.K. Akhtar, S.E. Pratsinis, and S.V.R. Mastrangelo: Vapor synthesis of Al-doped titania powders. J. Mater. Res. 9, 1241 (1994).

49. R. Strobel and S.E. Pratsinis: Effect of solvent composition on oxide morphology during flame spray pyrolysis of metal nitrates. Phys. Chem. Chem. Phys. 13, 9246 (2011).

50. R.C. Doman, J.B. Barr, R.N. McNally, and A.M. Alper: Phase equilibria in the system CaO-MgO. J. Am. Ceram. Soc. 46, 313 (1963).
51. R.J. Reeder, G.M. Lamble, and P.A. Northrup: XAFS study of the coordination and local relaxation around $\mathrm{Co}^{2+}, \mathrm{Zn}^{2+}, \mathrm{Pb}^{2+}$, and $\mathrm{Ba}^{2+}$ trace elements. Am. Mineral. 84, 1049 (1999).

52. M.E. Shils, J.A. Olson, M. Shike, and A.C. Ross: Modern Nutrition in Health and Disease, $10^{\text {th }}$ ed. (Lippincott Williams \& Wilkins, Philadelphia, 2006).

53. S.R. Lynch: The effect of calcium on iron absorption. Nutr. Res. Rev. 13, 141 (2000) 